\title{
HUMAN RIGHTS OMBUDSMEN IN THE PANDEMIC - CHALLENGES IN PROTECTION OF VULNERABLE GROUPS
}

\author{
Ljubinko Mitrović, PhD, Full professor \\ Human Rights Ombudsman of Bosnia and Herzegovina \\ Jovana Surutke 13, Banja Luka \\ bl.ombudsmen@ombudsmen.gov.ba
}

\section{Predrag Raosavljević, PhD, Full professor}

Assistant Human Rights Ombudsman of Bosnia and Herzegovina

Jovana Surutke 13, Banja Luka

praosavljevic@ombudsmen.gov.ba

ABSTRACT

Pandemic of virus COVID-19 posed numerous and unprecedented challenges to citizens and authorities which required shift in behavior and actions of all segments of society. Representing Ombudsmen Institution of Bosnia and Herzegovina, authors shared their experience in monitoring implementation of the decisions of all levels of government and presented challenges in striking the right balance between interests of public health and protection of rights of vulnerable groups. Public authorities in Bosnia and Herzegovina have passed emergency measures aimed at containing the spread of virus, but some of them failed to maintain human rights standards. Following the decisions of crisis centers to limit the freedom of movement, it was necessary to secure rights of children to education, protection from domestic violence and neglect in the family context. In introducing online education, authorities were asked to adapt recognition and grading system to the children in different conditions and circumstances, especially to the children with difficulties in development, children living in poverty and on margins of society such as Roma children or those living in institutions. Ombudsmen Institution registered increase in the number of domestic violence cases because measures limiting freedom of movement had impact on victims' ability to seek help from trusted sources, usually members of immediate family or representatives of law enforcement agencies. Having in mind that large number of citizens could not afford access to the official gazettes in any form, Ombudsmen requested that all enacted legislation be accessible online recommended that the decision banning reporters from conferences be reconsidered, guided by the right of citizens to be informed of their government actions. Examining the practice of placing COVID stickers on mail by the Post Office, Ombudsmen issued recommendation to stop such practice as it was deemed disproportional to the right to privacy and protection of personal data, while the pro- 
tection of postal workers could have been ensured by other protective measures. It also became evident that national budgetary capacities had to be increased in order to prevent deterioration in provision of basic public services such as health and social protection, since economic consequences of the pandemic were disproportionally felt by the groups exposed to poverty, such as Roma, refugees or migrants. Drawing conclusion from concrete cases, authors offer review of particular emergency measures, analyze their adequacy, justifiability and timeliness, while presenting authorities' response to Ombudsmen's findings in formulating more adequate and efficient but, at the same time, least intrusive measures taken in response to the disaster. In search of common response to such widespread phenomenon, governments should recognize the intention of Ombudsmen Institutions to be in "permanent session" over protection of vulnerable groups and should more actively involve it in discussions on emergency measures and their effect on human rights and freedoms. It proved to be better suited to act quickly, to apply more effective remedies and to correct government actions thanks to its knowledge of the local context than traditional institutions for protection of human rights, such as constitutional courts, international courts or treaty bodies.

Keywords: pandemic, human rights, ombudsmen, social protection, vulnerable groups

\section{INTRODUCTION}

Pandemic of virus COVID-19 posed numerous and unprecedented challenges to citizens and authorities which required shift in behavior and actions of all segments of society, from the decision makers to every individual. For the first time in history, all countries are concurrently affected by the same emergency crisis situation which swayed pursuit of the whole list of individual rights. In search of the best comparative solutions and practices, it is therefore useful to draw on varied experiences of institutions who acted as first responders to human rights violations in face of such challenges. Within its mandate of human rights protection, Ombudsmen Institution of Bosnia and Herzegovina monitors implementation of the decisions of all levels of government where the main challenge remains striking the right balance between interests of public health and protection of rights of vulnerable groups. Just as in other countries, public authorities in Bosnia and Herzegovina have passed emergency measures aimed at containing the spread of virus. Some of the decisions, however, failed to maintain human rights standards or did not take into consideration needs of vulnerable groups of citizens, such as children, women or those on social welfare. At the same time, civil rights such as right to access public information or media freedoms were constrained which required intervention of independent bodies. Reason for enacting such measures was the need to protect life and health of citizens in times of emergency, but they nonetheless had serious impact on many basic rights such as freedom of movement, economic liberties and activities or right to social protection. Generally, measures limiting fundamental rights and those aimed at prevention of the spread of the virus require special scrutiny, prompt reaction and close coordination between crisis centers and other competent authorities. 
Such task proved to be a challenging one in a country with the divided jurisdiction between different levels of government, plurality of legal systems and complex administrative structure established by the Dayton Peace Agreement. Specific dilemmas on application of human rights standards, daily struggles to choose the way forward and maintain the course of action in face of protests and complaints are illustrated by concrete examples and case studies presented in the article. Pandemic brought fight against discrimination on completely different level in Bosnia and Herzegovina, where de facto inequality was caused by the fact that different levels of government pursued separate and uncoordinated efforts to contain the spread of the virus. Therefore, it not only deepened the existing divisions as it was the case in other parts of the world, but new divisions appeared in all spheres of life, depending where the citizens resided within the country. The goal of this analysis is to address main challenges in securing legality, transparency and proportionality of the measures and actions taken by the authorities, usually limiting or altogether suspending citizens' rights. In line with customary international law and practice, public health emergency can serve as legitimate reason for derogation of fundamental rights and freedoms, but it is indisputable that such emergency measures should be subject to periodic and independent review. It is precisely the intention of authors to review particular emergency measures, analyze the adequacy, justifiability and timeliness of measures taken by the government authorities and to present challenges in implementation of required standards in local context. With such analysis in hand, public authorities, particularly in legislative branch, can be facilitated in formulating more adequate and efficient but, at the same time, least intrusive measures taken in response to the disaster. It will also be demonstrated how the work of national human rights mechanisms themselves have been affected in response to the pandemic taking into account that it is impossible to know how long the pandemic will last and what the total consequences will be. Citizens' compliance with the protective epidemiological measures was limited, partly due to existing mistrust of the authorities. General recommendations from international authorities proved to be of little avail to numerous and varied incidents in reality, where decision had to be brought with utmost urgency, with no space for generally welcomed international support, expertise or cooperation. Even courts including local courts and European Court of Human Rights had to temporarily close its doors, postpone the hearings and delay decisions in cases brought to their attention. In the void that was created, Ombudsmen Institution relied on its decades long experience with crisis relief, sensibility developed in post-conflict environment and ability for quick reaction sharpened by several emergencies in recent past. ${ }^{1}$ Its flexible, unbureaucratic and customized ap-

2014 unrest in Bosnia and Herzegovina, available at: [https:/en.wikipedia.org/wiki/2014_unrest_ in_Bosnia_and_Herzegovina\#: : :text=The\%202014\%20unrest $\% 20$ in $\% 20$ Bosnia,and\%20with\%20 the\%20aim\%20of], Accessed 13 March 2021; 2014 Southeast Europe floods, available at: [https:// 
proach, not bound by strict rules of procedures, proved to be crucial in finding solutions accepted by the government while being attuned to the needs of population.

\section{RIGHTS OF CHILD}

Since the outbreak of pandemic, Ombudsmen have issued umber of recommendations $s^{2}$ aimed at protection of the rights of child and securing their best interest. Following the decisions of crisis centers to limit the freedom of movement ${ }^{3}$, it was necessary to secure rights of children to education, protection from domestic violence and neglect in the family context. Faced with many uncertainties regarding duration, effects and outcome of the pandemic, educational institutions adopted measures aimed at uninterrupted completion of the school year, by introducing online education. ${ }^{4}$ In doing so, they were reminded of their obligation to adapt recognition and grading system to the children in different conditions and circumstances, specially to the children with difficulties in development, children living in poverty and on margins of society such as Roma children, those deprived of liberty (e.g. in correctional facilities) or those living in institutions, such as children without parenting. Ombudsmen called upon educational authorities to issue clear guidance aimed at providing all necessary conditions for continuation of classes, including those related to hygiene, space and distance, staff and security. Many parents, citizens and NGOs expressed their dissatisfaction with complete prohibition of movement for all, including children, that was in place during first couple of months of the pandemic. ${ }^{5}$ Ombudsmen carefully assessed views and opinions expressed by the citizens and at the same time called upon authorities to take into consideration best interest of the child when adopting or reviewing measures taken in protection of public health. This process resulted in the decision ${ }^{6}$ of the Constitutional Court of Bosnia and Herzegovina, which ruled that complete and indefinite ban violated rights of appellants to freedom of movement and it was subsequently lifted. At the same time, Ombudsmen issued opinion according to which the limitations of office hours of competent authorities presented the

en.wikipedia.org/wiki/2014_Southeast_Europe_floods], Accessed 13 March 2021; 2015 European migrant crisis, available at: [https://en.wikipedia.org/wiki/European_migrant_crisis], Accessed 13 March 2021, for the parts to Bosnia and Herzegovina see: Lilyanova, V., The Western Balkans Frontline of the migrant crisis, European Parliamentary Research Service, 2016.

2 Human Rights Ombudsman of Bosnia and Herzegovina, Recommendation no. P-86/21, P-127/20, P-59/20 and P-92/20.

3 Decisions no. 40-6-148-34/20 dated 20.03.2020 and 12-40-6-34-1/20 dated 27.03.2020.

4 Conclusion no. 01-3/20 dated 17.03.2020.

5 Human Rights Ombudsman of Bosnia and Herzegovina, Complaints no. Ž-SA-01-284/20, Ž-BL-01$311 / 20$ and Ž-LI-01-268/20.

6 Constitutional Court of Bosnia and Herzegovina, AP - 1217/20, dated 22.04.2020. 
risks for the increase of numbers of domestic violence incidents. Limited social contacts, unfortunately, proved to be detrimental to protection of rights of child within the family context. In their decisions, Ombudsmen made reference to the views of the United Nations Committee on Rights of Child which stated that limitations of movement can expose children to more physical and psychological violence at home, and issued recommendations to the member states to review measures limiting fundamental freedoms and to maintain only those that are necessary, proportional and minimal. ${ }^{7}$ Analyzing responses from government during first months of pandemic, it transpired that lack of financial resources affected measures aimed at securing the best interest of child. Ombudsmen issued recommendations to the authorities that core services such as emergency measures of removing children from violent surrounding must not be affected. In that regard, it was underlined that all workers coming into direct contact with beneficiaries of public services must be provided with safety gear and uniforms as matter of priority, such as those employed by centers for social protection, judiciary or police. Accommodation of victims of domestic violence had to be adapted to the exigencies of pandemic, especially in cases of mandatory self-isolation, taking into account limited capacities of the institutions, foster families and shelters. Furthermore, it was necessary to ensure timely resolution of the court cases dealing with cases of child neglect and/or violence, which in turn required adjusting work organization in all involved agencies, such as police, prosecutor's office, social protection services, lawyers and correctional institutions for minors. In court cases involving detention or violence against minors, particular attention had to be accorded to temporary measures or court injunctions', especially against abusive parents.

\section{WOMEN RIGHTS}

Relevant to its function of Equality Body, Ombudsmen Institution established that consequences of Corona pandemic disproportionally affect women, since shift to information technologies in conducting business does not equally suit women and men, especially in rural areas. Women globally do almost as much unpaid care and domestic work as men, and they are more likely than men to face additional care giving responsibilities when schools close, making it harder to maintain paid employment. ${ }^{8}$ At the same time there was evident lack of state efforts to educate, train or inform women or facilitate their adaptation to the new form of economy. Through regular contacts with government authorities, it became apparent that emergency response centers did not include representatives of

The Youth Justice Legal Center, COVID-19: United Nations Committee on the Rights of the Child recommendations for States, London, 2020.

8 Human Rights Watch, Human Rights Dimensions of COVID-19 Response, New York, 2020. 
civil societies, which would ensure better protection and realization of individual rights of the members of the most discriminated groups, while, at the same time, ensuring better transparency in the process of enacting restrictive and other emergency measures. During the period of March 2020 - March 2021, Ombudsmen Institution registered increase in the number of domestic violence cases and cases involving violence against women in general. ${ }^{9}$ It is estimated that such increase was predicated upon measures limiting freedom of movement, since it had impact on victims' ability to seek help from trusted sources, usually members of immediate family, or representatives of law enforcement agencies. ${ }^{10}$ Faced with limited government capacities for emergency shelter, police officers' response was indifferent to reports of the violence, according to several complaints. ${ }^{11}$ Safe houses did not receive financial or any other aid, while in one of the cases, there were no staff present except the night guard and there was lack of essentials such as food.

In cases of domestic violence, victims usually initially turn to immediate family members and friends rather than authorities or centers for social protection. Risk of domestic violence increased upon introduction of measures limiting freedom of movement (during night hours) and imposing mandatory isolation for individuals at risk. Stress from potential financial losses, continuous stay of all family members at the same residence, additional duties placed on members of the same family and limited access to all types of services proved to have negative effect on women, children and elderly. In that context, Ombudsmen of Bosnia and Herzegovina, while respecting orders issued with the aim of containing the spread of the virus by crisis centers in Republika Srpska, Federation of Bosnia and Herzegovina and Brcko District made recommendations to the authorities:

- to raise awareness of impact of social distancing and restriction of movement to women, children and elderly who are at risk of being exposed to domestic violence;

- to establish designated services for individuals at risk of domestic violence such as hotlines or platforms for online reporting of incidents and to duly inform the public of such options, and

- to ensure that, regardless of exigencies of situation caused by COVID-19 pandemic, promptly process reports of domestic violence.

At the same time, Ombudsmen of Bosnia and Herzegovina made public appeal, reminding all victims of domestic violence of their possibility to address Institu-

Institution of Human Rights Ombudsmen of Bosnia and Herzegovina, Annual Report 2020, p. 138.

10 Human Rights Ombudsmen of Bosnia and Herzegovina, Complaint no. Ž-BL-06-496/20.

11 Human Rights Ombudsmen of Bosnia and Herzegovina, Complaint no. Ž-BL-06-46/20 
tion of Human Rights Ombudsmen in cases they feel their rights have not been sufficiently or effectively protected by competent authorities.

\section{RIGHT OF JOURNALISTS AND ASSOCIATIONS TO ACCESS TO PUBLIC INFORMATION}

During 2020 dozens of journalists, NGOs and citizens' associations reported difficulties in accessing legislation and other general legal acts, citing Council of Ministers of Bosnia and Herzegovina, entity governments and Government of Brcko District as responsible parties.

According to the applicable legislation at all levels of government, no legal act can enter into force before being published in the Official Gazette, which are public companies responsible to the executive branch. In order to ensure compliance with the regulation that applies to them, citizens must have access and knowledge of their content, but those publications are available only to the subscribers, whether in print or electronic form. Having in mind that majority of citizens in Bosnia and Herzegovina live at the edge of poverty, which was exacerbated by the pandemic, many of them could not afford access to the official gazettes in any form. Ombudsmen requested that all enacted legislation be accessible online or in other suitable form, reasoning that public interest in this domain overweighs commercial interests, since gazettes are publicly financed and serve as an important tool in realization of right to be informed and notified of all legislation in place. Furthermore, Ombudsmen issued recommendation ${ }^{12}$ to crisis centers at Republika Srpska and Federation of Bosnia and Herzegovina to undertake necessary measures to publish all their decisions in print or digital media, in the most simple and easily accessible manner, to avoid any misunderstanding or confusion on the part of those affected.

Journalists submitted complaints ${ }^{13}$ alleging that government authorities organize press conferences without presence of media representatives. Such complaints were based on the fact that journalists did not have opportunity to engage in direct dialogue with public officials during press conferences, which can lead to censorship and incomplete informing of the general public. They also claimed that practice of crisis centers varied from time to time, sometimes allowing for physical presence of maximum three journalists, for example, or receiving questions through e-mail or complete ban. After assessing all relevant standards Ombuds-

\footnotetext{
12 Human Rights Ombudsmen of Bosnia and Herzegovina, Decision no. Oi-K-BL-114/2020 dated 13.04.2020.

13 Human Rights Ombudsmen of Bosnia and Herzegovina, Complaint no. SA-05-345/20
} 
men of Bosnia and Herzegovina called for adoption of measures respecting principles of good governance and rule of law as well as proactive transparency. ${ }^{14}$ Some of the negative effects of complete bans were complete withdrawal of media from coverage of press conferences. ${ }^{15}$ In their decisions, Ombudsmen made reference to the verdict ${ }^{16}$ of the Constitutional Court of Bosnia and Herzegovina which reasoned that "'...) such event was unprecedented in recent history and thus affected functioning of all executive and generally, public bodies." Ombudsmen equally took into consideration arguments stating that the government faced the task of protecting public health, while at the same time ensuring access to information and other fundamental rights.

Government explained that it is often necessary to opt for more restrictive measures, at least in initial phases, which are periodically evaluated and only leaving those that are proportional to the goal of preserving health of all.

In the interest of securing freedom of expression and access to information, Ombudsmen called for crisis centers to consider alternative mechanisms they have at their disposal, such as using information technologies, better protection preventing physical contact, larger conference venues or even open venues. Ombudsmen also recommended that the decision banning reporters from conferences be reconsidered, taking into account everybody's health including their own.

\section{RIGHTS OF PERSONS INFECTED WITH COVID}

In order to demonstrate and examine treatment of persons infected with COVID-19, we hereby present one of the most illustrative cases ${ }^{17}$ submitted to the attention of Ombudsmen Institution during 2020. Complainant and his wife entered period of self-isolation following positive results for one of them, after which they notified all their contacts of their status, including employers. On July 22, 2020, employee of postal services BH Post Office Ltd. Sarajevo delivered decision on isolation from Ministry of Health of Canton Sarajevo to them, without protective mask, in front of the apartment building where they reside, saying aloud that he will leave the envelope in front of the door because they are infected. Complainants were not initially aware how the serviceman knew their status until they

\footnotetext{
14 Human Rights Ombudsmen of Bosnia and Herzegovina, Recommendation no. P-68/20

15 For example, reaction of media to such measures can be found at: [https://media.ba/bs/magazin-novinarstvo/medijski-bunt-u-hercegovini]; also: [https://media.ba/bs/magazin-novinarstvo/komuniciranje-kriznih-stabova-suzen-prostor-za-novinarska-pitanja] and bljesak.info, among others. Accessed 13 March 2021.

16 Constitutional Court of Bosnia and Herzegovina, AP-1217/20.

17 Human Rights Ombudsmen of Bosnia and Herzegovina, Complaint no. Z-BL-06-281/20.
} 
saw inscription on the envelope stating „CAUTION!!! PERSON INFECTED WITH CORONA VIRUS“

Complainants contacted Cantonal Government asking why they are being publicly discriminated in such manner and they received response it was internally agreed procedure put in place to protect safety of postal workers. Ombudsmen initially contacted Agency for Postal Services asking for legal basis or formal decision affecting delivery of mail during pandemic and whether disputable stickers had legal basis. In their response, responsible Agency stated that due to pandemic caused by COVID-19 virus, Instruction regarding changes in delivery of mail was published in the Official Gazette of Bosnia and Herzegovina no. 23/20 according to which:

- Court mail shall be delivered in only one attempt

- Postman will deliver the mail in the mailbox or in front of the door of the residence with approval of recipient

- Instead of signature of receipt postman will make remark „COVID-19“ on the envelope slip and „C-19" in the registry book

Instruction will be valid until the Decision of Council of Ministers on declaring emergency at the territory of Bosnia and Herzegovina remains in place. ${ }^{18}$

In assessing legality of introduced measures, Ombudsmen invoked Law on rights, obligations and responsibilities of patients receiving health care. ${ }^{19}$ According to basic principles of that law, everyone is entitled to respect of human dignity and protection of personal data, including protection of information on status of their health. According to the same law, healthcare workers are forbidden from disclosing details about patient's health to any third party. According to the Law on personal data of Bosnia and Herzegovina, ${ }^{20}$ information pertaining to the health of any individual falls under the „special category of personal data“.

Ombudsmen equally assessed measures introduced by the $\mathrm{BH}$ Postal Service aimed at protecting their workers in their daily activities, especially during contacts with customers which includes wearing protective masks, gloves, using disinfection products or keeping distance. Specifically, Ombudsmen analyzed claims that Post Office workers have approximately 750 direct contacts with customers daily and that stickers on envelopes were introduced as protective measures, and the Instruction mandating such practice was largely based on general principles of

\footnotetext{
18 „Official Gazette of Bosnia and Herzegovina“ no. 18/20.

19 "Official Gazette of the Federation of Bosnia and Herzegovina" no. 40/10.

20 Article 3.
} 
Law on postal services of Bosnia and Herzegovina and recommendations of Crisis centers of Federal Ministry of Health. Ombudsmen reasoned that institutions on all levels of government, which were involved in detecting infected citizens, were undoubtedly processing personal data and had to abide by the law on protection of personal data of Bosnia and Herzegovina. As the identity of recipients could easily be established and linked to the status of their health, it was evident that their privacy was violated and they were discriminated on the basis of their health condition.

According to the law, ${ }^{21}$ discrimination is any different treatment, including exclusion, limitation or advantage based on real or supposed characteristics, including health condition. There are exceptions from the prohibition of unequal treatment, but such exceptions have to be based on law ${ }^{22}$, necessary in democratic society and proportional to the legitimate purpose they serve. In concrete case, such practice was not based on law, but rather on instruction that was not adopted in standard legislative procedure. Although it served legitimate purpose of protecting public health, it was not deemed proportional since the protection of postal workers could have been ensured by other protective measures, such as maintaining distance, use of masks, special clothing or disinfects. Equally, COVID-19 is not the only contagious disease and such measures were not introduced in any other cases, nor such patients' personal data was revealed to anyone. Having taken all facts into consideration, Ombudsmen issued recommendation ${ }^{23}$ to $\mathrm{BH}$ Post Office to stop the practice of placing stickers on envelopes addressed to infected citizens which was duly implemented.

\section{SOCIAL BENEFITS RECIPIENTS}

In the outset of COVID-19 pandemic, Ombudsmen made appeal ${ }^{24}$ to all authorities to put all human rights including economic and social rights in focus of implementation of emergency measures, in order to overcome challenges resulting in deterioration of standard of living, health services and protection of human dignity. However, due to heritage of reduction of public expenditures caused by global financial crisis of 2008. and 2009., which deepened social inequalities within and between European countries, health and social services

21 Law on prohibition of discrimination of Bosnia and Herzegovina, „Official Gazette of Bosnia and Herzegovina" no. 59/09 and 66/16.

22 Ibid, Art. 5.

23 Human Rights Ombudsmen of Bosnia and Herzegovina, Recommendation no. P-136/20.

24 Human Rights Ombudsmen of Bosnia and Herzegovina, Press Statement dated 06.05.2020. available at: [https://www.ombudsmen.gov.ba/Novost.aspx?newsid=1525\&lang=EN], Accessed 14 March 2021. 
were not prepared to respond to emergency situation caused by the pandemic. It was therefore essential to provide funds in public budgets for implementation of fiscal policies based on respect for fundamental freedoms and with due regard to the needs of marginalized groups. Ombudsmen reminded the state authorities of their international obligations under human rights treaties which require from them to use maximum of available resources to achieve complete realization of economic and social rights, as quickly and efficiently as possible. Measures from authorities were specifically scrutinized to ensure that state is not deviating from maintained standards of services and that is successful in ensuring de facto equality by mitigating disproportional effects to those at higher risk. In order to achieve such goals, crisis centers were called to raise transparency of the process of adoption of emergency measures and to include those who are directly affected by them. ${ }^{25}$ In several cases, Ombudsmen made recommendations ${ }^{26}$ to the governments to consider providing financial aid to businesses and institutions particularly if their activity was related to accommodation, nurture, water, sanitation, education, social insurance and employment. Regardless of the budgetary constraints imposed by international and European financial institutions, it became evident that national budgetary capacities had to be increased in order to prevent deterioration in provision of basic public services. Health and economic consequences of the pandemic were disproportionally felt by the groups exposed to poverty, racism or other forms of discrimination, such as Roma, refugees or migrants. It was therefore necessary to expand reach of social welfare during recovery and to consider different taxation policies, such as progressive rates and tax breaks for families in need. Equally, investments in health services needed to be understood more broadly to include access to accommodation, food, water and sanitation. That would not only help contain damaging effects of the pandemic but would increase resilience to future crisis. Support to reduction of risk from unemployment in emergency situation have to take into account workers in informal economy, such as women, migrants and low-skill workers, which make large percentage of workforce in Bosnia and Herzegovina. It is expected from state to draw lessons from past health epidemics and to adapt their policies to the needs of affected communities, while at the same time, coordinating relief efforts with other states to achieve maximum effects.

\footnotetext{
25 Human Rights Ombudsmen of Bosnia and Herzegovina, Press Statement dated 31.03.2020. available at: [https://www.ombudsmen.gov.ba/Novost.aspx?newsid=1513\&lang=EN], Accessed 13 March 2021.

26 Human Rights Ombudsmen of Bosnia and Herzegovina, Recommendation no. 33/21.
} 


\section{CONCLUSION}

Measures undertaken by the state authorities in response to COVID-19 pandemic, can significantly limit fundamental freedoms while also affecting regular functioning of the judicial and administrative system. Many governments were thus provided with an ideal pretext to crack down on dissent and exploit fears of their citizens, restricting their rights and passing emergency legislation which can have long-term consequences, beyond the health crisis. In undertaking actions to suppress the pandemic of COVID-19, significant threat occurs to rule of law, protection of human rights, protection from discrimination, right to privacy or protection of personal data and rights of socially endangered groups.

In all their work, Ombudsmen remind responsible parties that international documents on human rights form an integral part of Constitution of Bosnia and Herzegovina. It is true that these documents in fact foresee possibility of temporary derogation of individual rights and freedoms in times of emergency. Such derogations, however, can only be made in case there is danger to public (such as wartime) and they have to be necessary and required by exigencies of concrete situation. ${ }^{27}$ Those measures cannot be in disagreement with other obligations under international law while every High Contracting Party has a duty to fully notify Secretary General of the Council of Europe of the derogations it has made, their duration and cessation. It is clear from such provision that the possibility of derogation from basic rights is given to sovereign states and not to commercial enterprises or individual institutions.

When it comes to impact on protected groups, it became evident that pandemic of COVID-19 has made the most profound physical, emotional and psychological effects on children, that were further exacerbated by the state of emergency and limitation of movement. It was therefore necessary to factor health, socialization, education and economic rights of children into every decision passed by the crisis centers. Although emergency measures were passed on temporary basis, it is necessary to foresee the consequences in case pandemic lasts for longer time than anticipated and opt for least restrictive measures. Authorities should research alternative and creative solutions to enable children to enjoy their rights to leisure, entertainment, recreation and cultural and artistic activities. Online learning must not serve as a barrier to children with limited access to information technologies and cannot be seen as a replacement for traditional interaction between teachers and students. Core standard of living must be maintained despite the pressure on medical institutions, which includes provision of health, water,

27 European Convention for the Protection of Human Rights and Fundamental Freedoms, as amended by Protocols Nos. 11 and 14, 4 November 1950, ETS 5ECHR. 
sanitation and medical protection. Special attention needs to be afforded to children in need, such as those with disabilities, migrant children, asylum seekers and refugees, through introduction of tailored means of contact, communication and provision of services (E.g. home visits). In Bosnia and Herzegovina women comprise $74 \%$ of health workers ${ }^{28}$, including pharmacists and nurses increasing their risk of exposure and infection, which requires targeted measures to address the disproportionate impact of the crisis based on gender. Since many women work in informal sector, they may be the first to suffer the consequences of the crisis or lose their jobs, which necessitates the very best practices by governments, the public and private sector, international and national organizations, as alleviation of the negative socio-economic effects of this crisis should be shared. For example, expanded social insurance programs like unemployment benefits may permit female workers to stay on payroll and be paid when they cannot work because of a COVID-19 downturn.

The pandemic has also shone a light on the structural problems affecting health systems while years of austerity measures have led to a clear erosion of public health infrastructures, personnel and means. In some countries, including Bosnia and Herzegovina, response to the pandemic is clearly a result of the awareness of the weakness of the public health system and of the fact that the uncontrollable spread of the virus would overwhelm hospitals. When it comes to data confidentiality protection for the persons infected with the virus In the cases of Mokuta ${ }^{29}$ v. Lithuania and Z. v. Finland ${ }^{30}$ European Court of Human Rights ruled that the disclosure of such data may dramatically affect the private and family life of that person, as well as his status in society and employment if that person is exposed to shame and risk of persecution.

Encompassing implementation of enumerated rights, measures adjusting right of access to court should be designed to correspond to Article 6 of the European Convention of Human Rights, especially in cases with heightened attention of the judiciary, such as domestic violence or disputes involving rights of child. In case that the parliaments transfer additional powers and discretion to the executive, they must continuously safeguard the important checks-and-balances mechanisms and when new administrative simplifications are introduced, they should make the interaction between agencies and citizens easier. Finally, Government needs to recognize the intention of Ombudsmen Institution to be in „permanent session“

\footnotetext{
28 Babic-Svetlin, K., Analiza situacije Izvještaj o ravnoprovnosti polova u Bosni i Hercegovini, Sarajevo, 2009, p. 22.

29 Mockutè v. Lithuania (2018) Application no. 66490/09

30 Z. v. Finland (1997) Application no. 22009/93
} 
over protection of vulnerable groups and to more actively involve it in discussions on emergency measures and their effect on human rights and freedoms. Described examples proved Ombudsmen is better suited to act quickly, to apply more effective remedies and to correct government actions thanks to its knowledge of the local context than traditional institutions for protection of human rights, such as constitutional courts, international courts or treaty bodies.

\section{REFERENCES}

\section{BOOKS AND ARTICLES}

1. Babic-Svetlin, K., Analiza situacije Izvještaj o ravnoprovnosti polova u Bosni i Hercegovini, Sarajevo, 2009

2. Human Rights Ombudsmen of Bosnia and Herzegovina, Annual Report 2020

3. Human Rights Watch, Human Rights Dimensions of COVID-19 Response, New York, 2020

4. Lilyanova, V., The Western Balkans Frontline of the migrant crisis, European Parliamentary Research Service, 2016

5. The Youth Justice Legal Center, COVID-19: United Nations Committee on the Rights of the Child recommendations for States, London, 2020

\section{LIST OF NATIONAL REGULATIONS, ANCT AND COURT DECISIONS}

1. Constitutional Court of Bosnia and Herzegovina, AP - 1217/20

2. Decision of Council of Ministers on declaring emergency at the territory of Bosnia and Herzegovina remains in place, „Official Gazette of Bosnia and Herzegovina“ no. 18/20

3. Emergency crisis center Conclusion no. 01-3/20

4. Emergency crisis center Decision no. 12-40-6-34-1/20

5. Emergency crisis center Decision no. 40-6-148-34/20

6. Human Rights Ombudsman of Bosnia and Herzegovina, Complaint no. Ž-SA-01-284/20

7. Human Rights Ombudsman of Bosnia and Herzegovina, Complaint no. Ž-BL-01-311/20

8. Human Rights Ombudsman of Bosnia and Herzegovina, Complaint no. Ž-LI-01-268/20

9. Human Rights Ombudsman of Bosnia and Herzegovina, Complaint no. Ž-BL-06-496/20

10. Human Rights Ombudsman of Bosnia and Herzegovina, Complaint no. Ž-BL-06-46/20

11. Human Rights Ombudsman of Bosnia and Herzegovina, Recommendation no. P-86/21

12. Human Rights Ombudsman of Bosnia and Herzegovina, Recommendation no. P-127/20

13. Human Rights Ombudsman of Bosnia and Herzegovina, Recommendation no. P-59/20

14. Human Rights Ombudsman of Bosnia and Herzegovina, Recommendation no. P-92/20

15. Human Rights Ombudsmen of Bosnia and Herzegovina, Complaint no. SA-05-345/20

16. Human Rights Ombudsmen of Bosnia and Herzegovina, Complaint no. Z-BL-06-281/20

17. Human Rights Ombudsmen of Bosnia and Herzegovina, Decision no. Oi-K-BL-114/2020

18. Human Rights Ombudsmen of Bosnia and Herzegovina, Recommendation no. P-68/20 
19. Human Rights Ombudsmen of Bosnia and Herzegovina, Recommendation no. P-136/20

20. Human Rights Ombudsmen of Bosnia and Herzegovina, Recommendation no. P- 33/21

21. Law on prohibition of discrimination of Bosnia and Herzegovina, „Official Gazette of Bosnia and Herzegovina" no. 59/09 and 66/16

22. Law on rights, obligations and responsibilities of patients receiving health care, „Official Gazette of the Federation of Bosnia and Herzegovina" no. 40/10

\section{ECHR}

1. European Convention for the Protection of Human Rights and Fundamental Freedoms, as amended by Protocols Nos. 11 and 14, 4 November 1950, ETS 5ECHR

2. Mockutè v. Lithuania (2018) Application no. 66490/09

3. Z. v. Finland (1997) Application no. 22009/93

\section{WEBSITE REFERENCES}

1. 2014 Southeast Europe floods, [https://en.wikipedia.org/wiki/2014_Southeast_Europe_ floods], Accessed 13 March 2021

2. 2014 unrest in Bosnia and Herzegovina, [https://en.wikipedia.org/wiki/2014_unrest_in_ Bosnia_and_Herzegovina\#: : :text=The $\% 202014 \% 20$ unrest $\% 20$ in $\% 20$ Bosnia,and $\% 20$ with\%20the\%20aim\%20of], Accessed 13 March 2021

3. 2015 European migrant crisis, [https://en.wikipedia.org/wiki/European_migrant_crisis], Accessed 13 March 2021

4. Human Rights Ombudsmen of Bosnia and Herzegovina, Press Statement of 06.05.2020, [https://www.ombudsmen.gov.ba/Novost.aspx?newsid=1525\&lang=EN], Accessed 13 March 2021

5. Human Rights Ombudsmen of Bosnia and Herzegovina, Press Statement of 31.03.2020, [https://www.ombudsmen.gov.ba/Novost.aspx?newsid=1513\&lang=EN], Accessed 13 March 2021

6. Komuniciranje kriznih štabova: Sužen prostor za novinarska pitanja, [https://media.ba/bs/ magazin-novinarstvo/komuniciranje-kriznih-stabova-suzen-prostor-za-novinarska-pitanja], Accessed 13 March 2021

7. Medijski bunt u Hercegovini, [https://media.ba/bs/magazin-novinarstvo/medijski-bunt-uhercegovini], Accessed 13 March 2021 